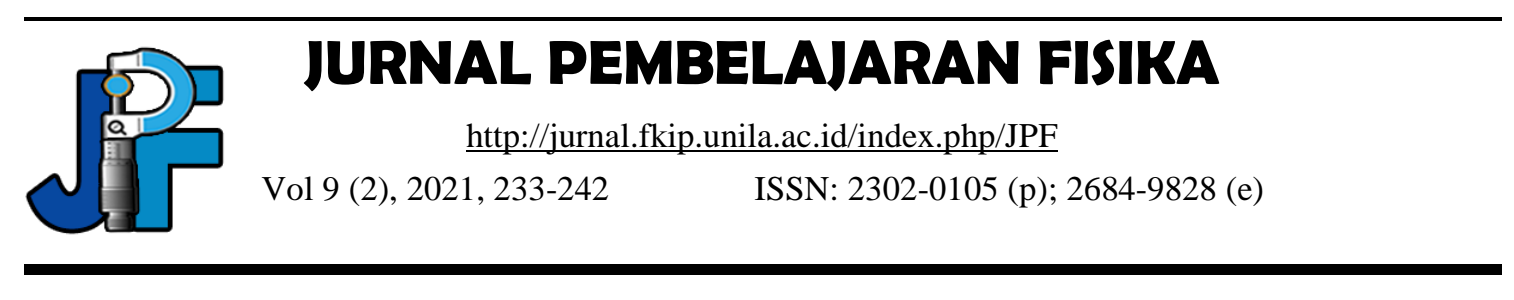

\title{
The Effect of Using Project Base Learning (PjBL) Models on Students' Creative Thinking Skills in Solar System Materials
}

\author{
Vivit Nurhikmah Havita ${ }^{1}$, Sjaifuddin ${ }^{2}$, Asep Saefullah ${ }^{3 *}$, Lukman Nulhakim ${ }^{4}$, Diana Ayu \\ Rostikawati $^{5}$ \\ 1,2,4 IPA Education Graduate Program, Sultan Ageng Tirtayasa University, Indonesia \\ ${ }^{3}$ Physics Education Graduate Program, Sultan Ageng Tirtayasa University, Indonesia \\ ${ }^{5}$ Industrial Engineering Education Graduate Program, Bina Bangsa University, Indonesia \\ *e-mail: asaefullah@untita.ac.id
}

\begin{abstract}
This study aims to determine the achievement and improvement of the abilities gained by students with project-based learning models $(\mathrm{PjBL})$. The method used in this study is a pre-experimental method with research design one group pretest-posttest. This study uses one class. The population of this study was all students of class VII A with total of 36 students. The study instrument used was a test of creative thinking skills and non-test abilities consisting creativity, presentation and percentage, and the implementation of the learning model. The result of this study obtained by paired t-test showed that there is a possibility of using the PjBL model to the creative thinking skills with a significance value of 0.000 . These results indicate that PjBL effects creative thinking skills. In addition, the improvement of creativity based on the test of creative thinking skills has a value of $0.56(56 \%)$ with medium category, the average value of innovative products is $85.71 \%$ with outstanding classes, and the performance \& percentage are 73 with good classes.
\end{abstract}

Keywords: creative thinking skills, project based learning (PjBL), solar system materials

DOI: http://dx.doi.org/10.23960/jpf.v9.n2.202110 


\section{INTRODUCTION}

Natural Sciences (IPA) is a systematic science that deals with natural phenomena and is based on observations. In contrast, the nature of science consists of three aspects, namely scientific products, scientific processes, and scientific attitudes (Saefullah, 2017). In the science learning process, a thinking process occurs, which requires students to think creatively in dealing with problems in science learning (Hartini, 2014).

Creativity is the result of the interaction between individuals and their environment, the ability to make new combinations based on data, information, or elements that already exist or are known previously, namely all experiences and knowledge that have been obtained during their lives, both in the school, family, and community environment (Nulhakim, 2020).

The results show that the creativity of Indonesian students is still very low. This is the result of research using the Test For Creative Thinking Drawing Production (TCD-DP) using samples from eight countries, including Indonesia (Anggraini, 2018). The results show that the creativity scores of Indonesian students get the lowest scores compared to other countries, such as the Philippines, India, and South Africa (Limont, 2006).

The results of field studies at one of the Junior High Schools (SMP) in Pandeglang also show that students' creative thinking skills are still low. This can be seen from the student products that have been made dominant without identifying indicators of creative thinking, for example in making a craft such as shady trees, paper flowers, and traditional houses which have high aesthetic value, but are lacking in terms of creativity value, this is because creative thinking indicators are not met in the creation that has been made (Suyanto, 2020).

One of the efforts to improve students' creative thinking skills is applying the Project-Based Learning ( $\mathrm{PjBL}$ ) model in the learning process. PjBL is a model that emphasizes students to learn independently by solving problems and producing a project or real creation (Rati, 2017).

In the PjBL model, creativity plays an essential role in designing or making a product. Therefore, some research results show that using the PjBL model can increase students' creativity (Nugraha, 2018). The PjBL model has several advantages : being integrated, working collaboratively, being disciplined, and improving communication (Sholekah, 2020). For this reason, the PjBL model can be used as a learning model to hone students' and enhance learning achievement.

In this study, the researcher wanted the project-making process to make students understand the existing theory easier. The final result of the $\mathrm{PjBL}$ model is a product of work produced by students in groups; this is intended to make students have the ability to work together (Fatimah, 2016).

The material for the solar system was chosen as the material used in the research. The Solar System consists of the sun, eight planets, and various celestial bodies such as satellites, comets, asteroids (Arum, 2019). The planets revolve around the sun in elliptical orbits (Ansori, 2013). 
Based on the description above, the researcher intends to research the effect of using the Project Base Learning ( $\mathrm{PjBL}$ ) model on students' creative thinking skills on the material of the solar system.

\section{METHOD}

The research method used is pre-experimental using one group pretest-posttest design, which is a technique to determine the effect before and after the treatment (Sugiyono, 2017). The design of this study is described as shown in table 1.

Table 1. One group pretest-posttest design

\begin{tabular}{lll}
$O_{1}$ & $X$ & $O_{2}$ \\
\hline
\end{tabular}

Description :

$\mathrm{O}_{1}=$ Pretest

$\mathrm{X}=$ Model PjBL

$\mathrm{O}_{2}=$ Posstet

This research was conducted in one of the junior high schools in the Pandeglang district. The population in this study were all students of class VII, with the research sample being class VIIA with a total of 36 students. The research sample was determined using the Cluster Random Sampling technique, a random sampling technique (Sugiyono, 2017).

The instruments used in this study were test and non-test instrument. The test instrument is creative thinking skills, while the non-test instrument is an observation sheet for the innovative process and creative products and presentations. Expert validators have validated the test instruments used.

According to Lestari (2018), there are four aspects of creative thinking skills, namely: 1) Fluency (fluent thinking skills), 2) Flexibility (flexible thinking skills), 3) Originality (original thinking skills), and 4) Elaboration (detailing skills). In addition, creative thinking skills can also be seen from the stages of the creative process and product results.

The data obtained in this study were the pretest and posttest scores of students' creative thinking abilities. The pretest is given before the learning process to know the students' initial creative thinking skills. Meanwhile, a posttest is given after students receive treatment in the form of learning using project-based learning model materials. To determine the increase in students' creative thinking skills after being given treatment, the pretest and posttest scores were processed through the normalized gain value equation (n-gain) using the following (Sugiyono, 2017).

$$
\langle g\rangle=\frac{S_{\text {post }}-S_{\text {pre }}}{S_{\max }-S_{\text {pre }}}
$$


Information :

$$
\begin{aligned}
& \langle g\rangle=\text { Normalized gain value } \\
& S_{\text {post }}=\text { Posttest Score } \\
& S_{\text {pre }}=\text { Pretest Score } \\
& S_{\max }=\text { Maximum score }
\end{aligned}
$$

The results of the acquisition of the n-gain value are then analyzed with the criteria as shown in table 2.

Table 2. n-gain categorization

\begin{tabular}{cc}
\hline n-gain & Interpretation \\
\hline$g>0,7$ & High \\
$0,3 \leq g \leq 0,7$ & Medium \\
$g<0,3$ & Low \\
\hline
\end{tabular}

\section{RESULT AND DISCUSSION}

The test instrument in the research has been validated first using the ANATES V4 software. The validation results show that the creative thinking skills test instrument has been declared and can be used for research purposes.

Before discussing the research results, here is one of the students' work products in the form of a miniature solar system, which consists of the sun and the arrangement of the planets.

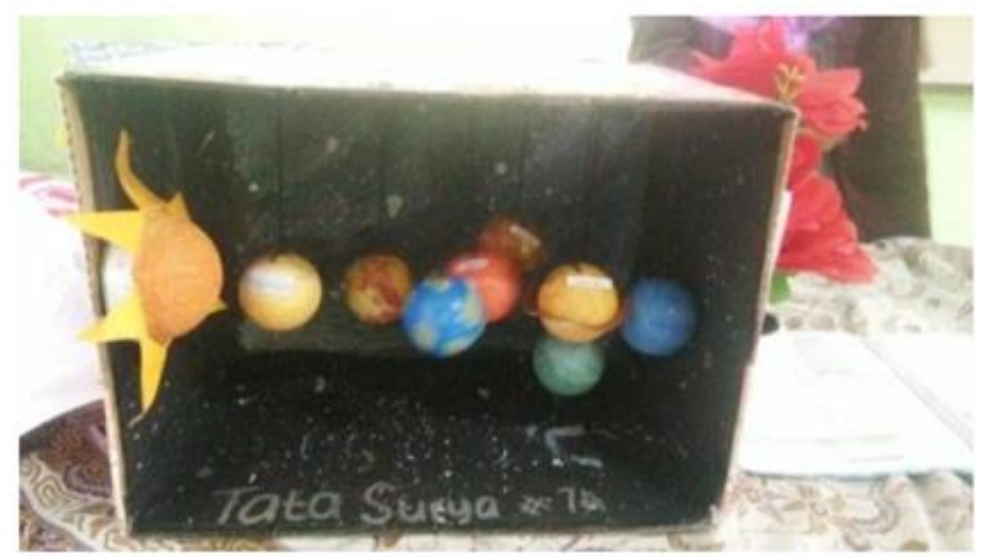

Figure 1. The students work a miniature solar system

The normality test results showed that the pretest and posttest data were normally distributed. This was evidenced by the obtaining of significance values of 0.25 and 0.63 , Which were $>0.05$. This means that the data is normally distributed, as shown in table 3. 
Table 3. The result of the normality test of the pretest and posttest data

\begin{tabular}{cccc}
\hline \multirow{2}{*}{ Data } & \multicolumn{3}{c}{ Shapiro wilk } \\
\cline { 2 - 4 } & Statistic & Df & Sig. \\
\hline Pre-test & .930 & 36 & .025 \\
\hline Post-test & .943 & 36 & .063 \\
\hline
\end{tabular}

After the data is normally distributed, the information is continued with homogeneity testing, the test is carried out to determine whether the data used is homogeneous or not. The results of the homogeneity test can be seen in table 4 .

Table 4. Homogeneity test result

\begin{tabular}{cccc}
\hline Levene statistic & df1 & df2 & Sig. \\
\hline 1.059 & 5 & 29 & .403 \\
\hline
\end{tabular}

The results of the homogeneity test showed a sig. (2-tailed) number of 0.000 (p 0.05). If the significance number is 0.05 , then the hypothesis in this study is accepted. This proves that the PjBL model influences students' creative thinking skills in the solar system material.

After the instrument went through the validity and reliability test phase, the researcher then carried out the Pre-test and Post-test in class. This pre-test was conducted to determine the students' initial knowledge to answer the question of creativity ability about the solar system. In comparison, the post-test was conducted to determine the students' creative thinking skills after being given treatment in the form of the application of PjBL.

The pre-test and post-test data that have been obtained are then processed to determine the level of students' ability to work on creativity questions about the solar system in terms of several indicators.

The creative thinking skill instrument contains 20 multiple-choice items representing each five items for fluent thinking, five items for flexible riview, five items for originality, and five entities for detailing skills. Researchers used these 20 items to measure students' creative thinking skills in the sampled class. The results of the research on the description of creative thinking abilities can be seen in Figure 2.

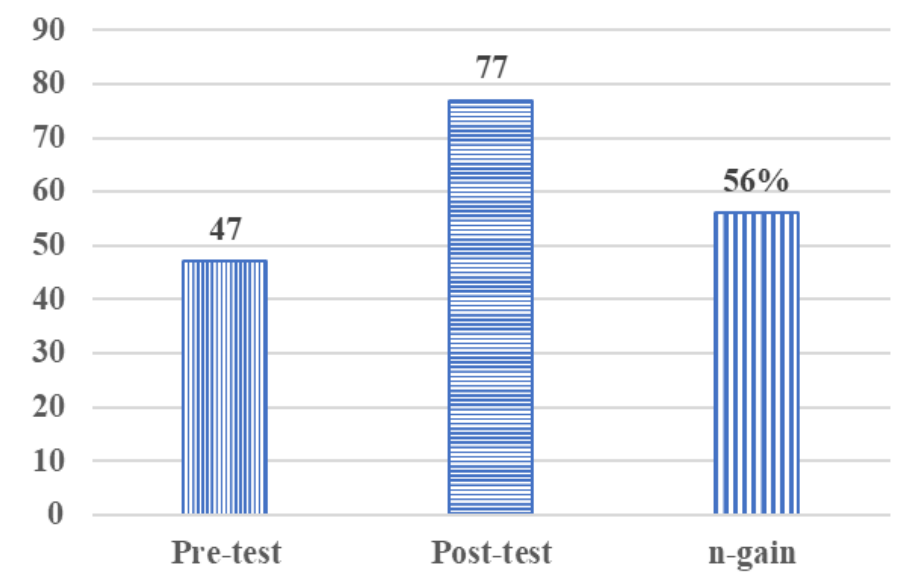

Figure 2. Pre-test, post-test, and n-gain data on creative thinking skills 
In Figure 3, it is known that the average value before and after being given treatment has a reasonably high difference. The creative thinking skills of students who receive learning through the $\mathrm{PjBL}$ model is higher than when the learning model has not been given. This shows that the application of the PjBL model is better in improving the creative abilities of class VII students. The n-gain value obtained is $0.56(56 \%)$, including the medium category (Archambault, 2009). This is in line with previous research, which stated that the $\mathrm{PjB}$ model positively affected students' creative thinking skills on static fluid material (Sari, 2018). The creative thinking skills test results in each indicator can be seen in Figure 3.

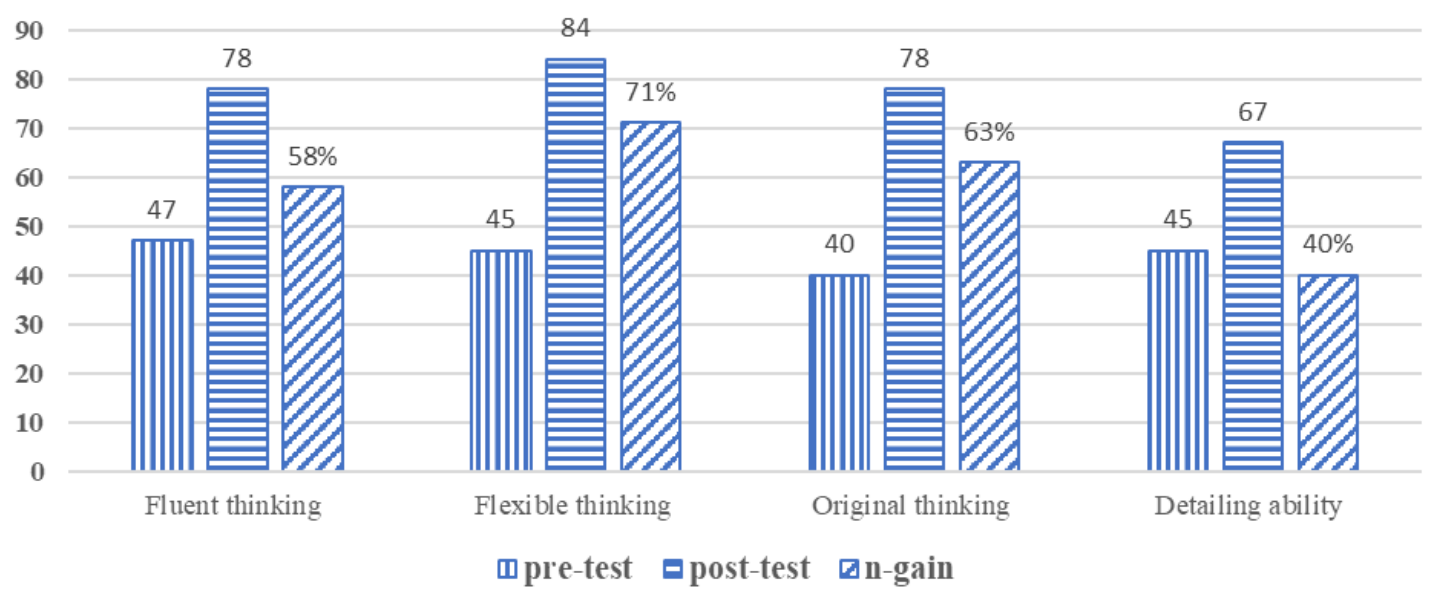

Figure 3. Pretest, posttest, and n-gain data diagrams for each indicator of creative thinking skills

Figure 3, shows that the values for each indicator have different percentages. The fluent thinking hand increased by $58 \%(0.58)$, the flexible thinking indicator increased by $71 \%(0.71)$, the original thinking indicator increased by $63 \%(0.63)$, and the detailing ability indicator increased by $40 \%(0.40)$. This result is in line with the research conducted by Pratiwi (2018), which showed that the PjBL model was able to improve student learning outcomes and scientific attitudes.

The highest thinking skill indicator is found in the flexible thinking indicator. Flexible thinking itself has sub-indicators such as having many alternatives in working. This certainly shows that students have many alternative ideas in planning and doing the final project. Meanwhile, the ability to interpret has the smallest increase compared to other indicators of creative thinking skills. The detailing ability indicator itself has subindicators, such as detailing the details of an idea or project object. This indicates that students are still weak in describing the ideas or final projects they are working on (Liliawati, 2011).

\section{Process}

Creative thinking skills are reviewed from the final result and from the process. There are five stages of the creative thinking skills process : 1. Preparation, 2. Incubation, 3. Illumination, 4. Verification, and 5. Presentation. This stage aims to determine how the performance during the learning process and product presentation of 
learning outcomes. The results of creative thinking skills in the steps of the process can be seen in Figure 4.

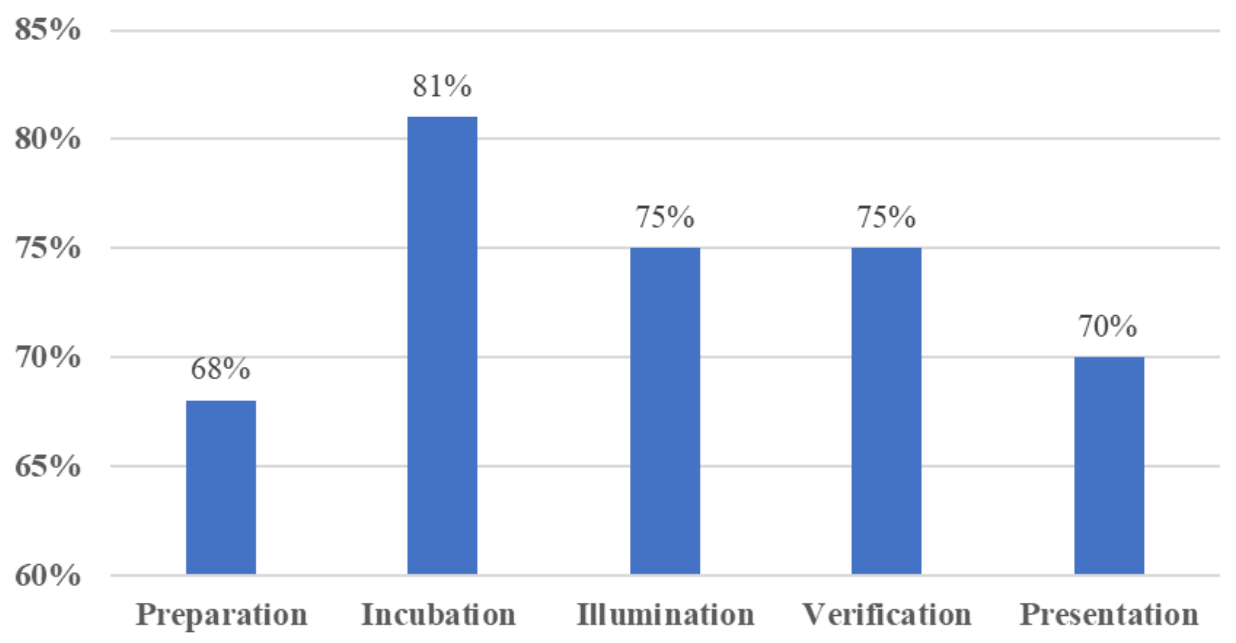

Figure 4. Performance Observation Result and product presentation

The preparation stage is where the mind must get as much information as possible that is relevant to the problem. At this stage, a value of $68 \%$ is obtained. While the incubation stage is the stage of trial solving. At this stage, got a value of $81 \%$.

The illumination stage is the stage for getting ideas or solutions to solve problems. At this stage, a score of $75 \%$ is obtained. In comparison, the verification stage is the stage for testing and evaluating the proposed solution at the illumination stage. A value of $75 \%$ is obtained at this stage, the same as the illumination stage.

The presentation stage is the stage of displaying the results of problem-solving in the resulting product. This stage has a distributive value of $70 \%$. Overall, the average value of the five steps is $74 \%$ which is included in the excellent category. These results indicate that the PjBL model can improve the product skills of learning outcomes (Arisanti, 2016).

\section{Product}

There are three indicators, 1. Recency, 2. Originality, and 3. Significance. Figure 5 shows the results for each hand of project-based learning outcomes. 


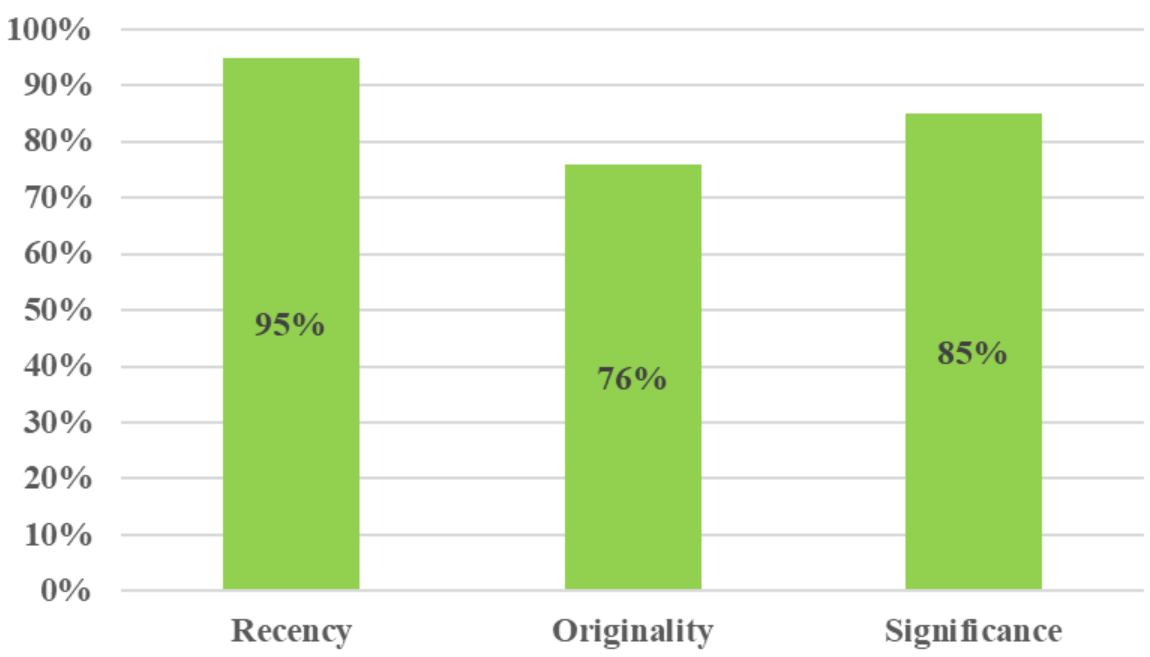

Figure 5. Percentage of creative product indicators

The smallest percentage gain is found in the originality indicator, $76 \%$. This is because students tend to follow existing works or products. Incomparison, the highest percentage is located in the renewability indicator, which is $95 \%$. While the meaningfulness indicator obtained a value of $85 \%$, this indicates that the resulting product can provide benefits to be used as a medium in learning.

The use of the PjBL model has a good and positive impact on the achievement of production values that can be categorized as very creative. This happens because, during the learning process from the first meeting to the third meeting, the teacher involves students in problem-solving. Discussion activities are carried out in each group; this aims to guide and monitor discussion activities carried out by the entire group. A good value for creative thinking skills is obtained by manufacturing products that meet all indicators.

\section{CONCLUSION}

The results showed that applying the project-based learning model (PjBL) could affect students' creative thinking skills in the concept of the solar system. This is evidenced by the results of the paired sample T-test which shows that the value of Sig (2-tailed) is less than 0.05 , namely $0.000(0.000<0.05)$. The application of the PjBL model also has a positive impact on increasing the value of students' creative thinking skills; this is evidenced by the n-gain value of $0.56(56 \%)$, which is included in the moderate category. The increase in creative thinking skills also occurred in all indicators: fluent thinking, flexible thinking, original thinking, and detailing skills. These results indicate that the PjBL model has a positive influence and can improve students' creative thinking skills on the material of the solar system. 


\section{REFERENCES}

Anggraini, R. (2018). Desain LKPD berbasis scientific approach untuk melatih keterampilan berpikir kreatif siswa pada materi suhu dan perubahannya: penelitian pendahuluan. Jurnal Pembelajaran Fisika.

Ansori, I. (2013). Analisis Kurikulum Ilmu Pengetahuan Bumi Dan Antariksa Pada Jenjang Sekolah Menengah Atas. WaPFi (Wahana Pendidikan Fisika), 76-83.

Archambault, I. (2009). Adolescent behavioral, affective, and cognitive engagement in school: Relationship to dropout. Journal of School Health, 408-415.

Ardianti, S. D. (2017). Implementasi project based learning (pjbl) berpendekatan science edutainment terhadap kreativitas peserta didik. Refleksi Edukatika: Jurnal Ilmiah Kependidikan.

Arisanti, W. O. (2016). Analisis penguasaan konsep dan keterampilan berpikir kreatif siswa SD melalui Project Based Learning. EduHumaniora| Jurnal Pendidikan Dasar Kampus Cibiru, 82-95.

Arum, W. F. (2019). The Effectiveness of Puzzle as Solar System Learning Media for Children with Disabilities. Jurnal Pembelajaran Fisika.

Fatimah, S. (2016). Pengaruh Pembelajaran IPA Menggunakan Project Based Learning (PJBL) Dan Seven Jumps Terhadap Keterampilan Proses Dan Karakter Sains Peserta Didik Pada Materi Peristiwa Alam. Prosiding Seminar Nasional Inovasi Pendidikan (pp. 160-172). Surakarta: FKIP UNS.

Hartini, T. I. (2014). Pengaruh berpikir kreatif dengan model problem based learning (pbl) terhadap prestasi belajar fisika siswa dengan menggunakan tes open ended. Jurnal Pendidikan IPA Indonesia.

Learning, A. p. (2016). Analisis penguasaan konsep dan keterampilan berpikir kreatif siswa SD melalui Project Based Learning. EduHumaniora| Jurnal Pendidikan Dasar Kampus Cibiru, 82-95.

Lestari, T. (2018). Membangun Keterampilan Berpikir Kreatif Siswa Melalui LKPD Berbasis Scientific Approach Materi Elastisitas dan Hukum Hooke: Penelitian Pendahuluan. Jurnal Pembelajaran Fisika.

Liliawati, M. W. (2011). Pembekalan Keterampilan Berpikir Kreatif Siswa SMA Melalui Pembelajaran Fisika Berbasis Masalah. Jurnal Pengajaran MIPA, 9398.

Limont, W. (2006). Investigation of the Prototypicality of Visual Stimuli in the Drawings of Seven-Year-Old Children. Empirical Studies of the Arts, 55-70.

Maghfiroh, A. F. (2017). Pengaruh Model Problem-Based Learning (PBL) Disertai Media Tiga Dimensi Terhadap Kemampuan Berpikir Kreatif Siswa Dan Hasil Belajar Siswa Dalam Pembelajaran Fisika Di Sma Negeri 4 Jember. Jurnal Pembelajaran Fisika, 33-39. 
Nugraha, A. R. (2018). Penerapan Model Pembelajaran Project Based Learning (Pjbl) Untuk Meningkatkan Kreativitas Dan Hasil Belajar Ipa Pada Siswa Kelas 5 Sd. KALAM CENDEKIA PGSD KEBUMEN, 9-15.

Nulhakim, L. (2020). Improving Students' Creative Thinking Skills Using ProblemBased Learning (PBL) Models Assisted by Interactive Multimedia. Jurnal Penelitian \& Pengembangan Pendidikan Fisika, 9-16.

Pradita, Y. (2015). Penerapan model pembelajaran Project Based Learning untuk meningkatkan prestasi belajar dan kreativitas siswa pada materi pokok sistem koloid kelas XI IPA semester genap Madrasah Aliyah Negeri Klaten Tahun Pelajaran 2013/2014. Jurnal pendidikan kimia, 89-96.

Pratiwi, D. E. (2018). Pengaruh Model Pembelajaran Sains Teknologi Masyarakat Dan Model Project Based Learning Terhadap Hasil Belajar Fisika Dan Sikap Ilmiah Siswa. Jurnal Pembelajaran Fisika, 13-21.

Rati, N. W. (2017). Model pembelajaran berbasis proyek, kreativitas dan hasil belajar mahasiswa. JPI (Jurnal Pendidikan Indonesia), 60-71.

Saefullah, A. (2017). Efforts to improve scientific literacy of students through guided inquiry learning based on local wisdom of Baduy's society. Jurnal Penelitian dan Pembelajaran IPA, 84-91.

Saefullah, A. (2021). Implementation of PjBL-STEM to Improve Students' Creative Thinking Skills On Static Fluid Topic. JIPF (Jurnal Ilmu Pendidikan Fisika), 149-157.

Saefullah, A. (2021). Implementation of PjBL-STEM to Improve Students' Creative Thinking Skills On Static Fluid Topic. JIPF (Jurnal Ilmu Pendidikan Fisika), 149-157.

Sari, W. P. (2018). Keterampilan Berpikir Kreatif Siswa SMA dalam Pembelajaran Project Based Learning (Pjbl) pada Materi Fluida Statis. Jurnal Pendidikan: Teori, Penelitian, dan Pengembangan, 751-757.

Sholekah, A. W. (2020). Peningkatan Motivasi Dan Hasil Belajar IPA Materi Pencemaran Lingkungan Melalui Model PjBL Siswa Kelas VII SMPN 9 Salatiga. Jurnal Pendidikan MIPA, 16-22.

Sugiyono. (2017). Metode Penelitian Pendidikan: Pendekatan Kuantitatif, Kualitatif, $R \& D$. Bandung: Alfabeta.

Surya, A. P. (2018). Penerapan model pembelajaran project based learning (PjBL) untuk meningkatkan hasil belajar dan kreatifitas siswa kelas III SD Negeri Sidorejo Lor 01 Salatiga. Jurnal Pesona Dasar.

Suyanto, E. (2020). The Effect of GIL Assisted Phyphox in Physics Learning towards Creative Thinking. Jurnal Pembelajaran Fisika. 